\title{
SELECTIVITY OF BENTAZON AND NICOSULFURON IN Crotalaria spectabilis INTERCROPPED WITH MAIZE CULTURE ${ }^{1}$
}

\author{
CASSIO HENRIQUE PEREIRA NOGUEIRA ${ }^{2 *}$, NÚBIA MARIA CORREIA ${ }^{3}$, LEONARDO JOSÉ PETEAN GOMES ${ }^{2}$, \\ PHELIPPE SANT'ANNA HONORIO FERREIRA ${ }^{2}$
}

\begin{abstract}
Corn intercropped with showy crotalaria allows better use of the agricultural year, having in the same period, economic return from grain yield and the benefits of the legume. The objective was to study the selectivity of the herbicides bentazon and nicosulfuron to C. spectabilis, the weed control and the corn development intercropping system. Two experiments were conducted in the field, one in late-season and the other one in regular growing season. The experimental design was the randomized block, with fourteen treatments and four replicates. Eight treatments with herbicides were studied: bentazon $\left(720 \mathrm{e} 960 \mathrm{~g}\right.$ a.i. ha $\left.{ }^{-1}\right)$, nicosulfuron $\left(16\right.$ e $48 \mathrm{~g}$ a.i. $\left.\mathrm{ha}^{-1}\right)$ and bentazon + nicosulfuron $(720+16 ; 720+48 ; 960+16 ; 960+48 \mathrm{~g}$ a.i. ha ${ }^{1}$ ). Moreover, six controls were maintained: sole corn and sole showy crotalaria (with and without weeds), corn and sunn hemp intercropped (with and without weeds). The herbicide bentazon isolated, in both dosages tested, was selective to C. spectabilis. Nicosulfuron in $48 \mathrm{~g}$ a.i. $\mathrm{ha}^{-1}$, isolated or in mixture with bentazon, promoved the best weed control. Corn affected the recoverability of showy crotalaria plants treated with herbicides. In intercrop of corn and C. spectabilis, both late and regular season had good results in corn yield, legume mass accumulation without the necessity of herbicides pulverization.
\end{abstract}

Keywords: Green manure. Showy crotalaria. Phytointoxication. Interference. Simultaneously sowing.

\section{SELETIVIDADE DE BENTAZON E NICOSULFURON PARA Crotalaria spectabilis EM CONSÓRCIO COM A CULTURA DO MILHO}

RESUMO - O consórcio de milho com crotalária possibilita o melhor aproveitamento do ano agrícola, tendo no mesmo período o retorno econômico com a produção de grãos e os benefícios da leguminosa. Objetivou-se com esse trabalho, estudar a seletividade dos herbicidas bentazon e nicosulfuron para Crotalaria spectabilis, o controle de plantas daninhas e o desenvolvimento do milho no sistema de consórcio. Dois experimentos foram desenvolvidos em campo, um no período de safrinha e outro no período de safra. O delineamento experimental foi em blocos ao acaso, com 14 tratamentos e quatro repetições. Foram estudados oito tratamentos com herbicidas: bentazon $\left(720\right.$ e $960 \mathrm{~g}$ i.a. ha $\left.{ }^{-1}\right)$, nicosulfuron $\left(16 \mathrm{e} 48 \mathrm{~g}\right.$ i.a. ha $\left.{ }^{-1}\right)$ e bentazon + nicosulfuron $(720+$ 16; $720+48 ; 960+16 ; 960+48 \mathrm{~g}_{\text {i.a. }}$ ha $^{-1}$ ). Além disso, foram mantidas seis testemunhas: milho e crotalária solteiros (com e sem plantas daninhas), milho e crotalária em consórcio (com e sem plantas daninhas). $\mathrm{O}$ herbicida bentazon isolado, nas duas dosagens testadas, foi seletivo para C. spectabilis. Nicosulfuron a $48 \mathrm{~g}$ i.a. $\mathrm{ha}^{-1}$, isolado ou em mistura com bentazon, promoveu o melhor controle das plantas daninhas. O milho afetou a capacidade de recuperação das plantas de crotalária tratadas com herbicidas. No consórcio de milho com $C$. spectabilis, tanto na safrinha como na safra, houve bons resultados de produtividade do milho e acúmulo de massa pela leguminosa sem a necessidade de aplicação de herbicidas.

Palavras-chave: Adubo verde. Crotalária. Fitointoxicação. Interferência. Semeadura simultânea.

\footnotetext{
${ }^{*}$ Corresponding author

${ }^{1}$ Received for publication in 07/13/2017; accepted in 02/11/2019.

Paper extracted from the master dissertation of the first author.

${ }^{2}$ Department of Crop Protection, Universidade Estadual Paulista "Júlio de Mesquita Filho", Jaboticabal, SP, Brazil; nogueirachp@gmail.com - ORCID: 0000-0002-8908-951X, leo_pgomes@hotmail.com - ORCID: 0000-0001-5625-3689, phellipesantanna@gmail.com- ORCID: 0000-0001-8356-1900.

${ }^{3}$ Embrapa Cerrados, Empresa Brasileira de Pesquisa Agropecuária, Brasília, DF, Brazil; nubia.correia@embrapa.br - ORCID: 0000-00025045-9798.
} 


\section{INTRODUCTION}

Showy crotalaria $(C$. spectabilis) originates from the Indo-Malayan region but is now distributed worldwide. It is an annual cycle legume, with slow initial growth and significant accumulation of dry mass and nitrogen, which varies according to the cultivation period owing to differences in photoperiod (CESAR et al., 2011; MATEUS; WUTKE, 2006). In agriculture, it is used as green manure to provide an increased yield of subsequent crops and assist in the control of weeds and nematodes (COSTA; PASQUALLI; PREVEDELLO, 2014; ERASMO et al., 2004; SANTOS et al., 2010).

Despite its advantages, $C$. spectabilis does not generate a direct economic return for the producer and, therefore, a wider adoption of its cultivation in crop rotation/succession systems is still limited. A potential alternative to address this problem is the intercropping of cultures, which makes better use of the crops by providing, in the same period, economic return from the production of grains and benefits of the intercrop species (GALVÃO et al., 2014).

The advantages of intercropping systems using maize and legumes, relative to monocropping, include the greater accumulation of dry matter, improved physical quality of the soil, and possibility of increasing the yields of subsequent crops (HEINRICHS et al., 2005; CORREIA; DANIEL; LEITE, 2012; GITTI et al., 2012). However, there is still a lack of data based on the implementation of intercropping systems, namely with regard to the methods of weed control.

Intercropped legumes can interfere with the development of weeds, depending upon the species, season of the year, and planting density (MARTINS, 1994; CORREIA; DANIEL; LEITE, 2012; CORREIA; FUZITA; DANIEL, 2012). However, while chemical control is still required in most situations, its use is limited because the herbicides must be selective in both the main crop and intercrop species (DAN et al., 2012).

Adequate products and doses should be used to avoid weed interference in maize, without affecting the recoverability of the intercropped species. However, the literature provides little information about the selectivity of herbicides in Crotalaria. Braz et al. (2016) reported that the herbicides imazethapyr, flumiclorac, bentazon, and the combination of clethodim + quizalofop, applied post-emergence, caused mild visual damage to the plants of C. spectabilis. The options are even more limited when only the herbicides registered for use with maize are considered.

For the intercropping maize + showy crotalaria system, there is a lack of information on the herbicide selectivity in showy crotalaria, weed control, and interference of showy crotalaria in the development of maize, especially when the species are sown simultaneously. Therefore, it is necessary to apply herbicides at adequate doses to inhibit the growth of Crotalaria and control weeds, without reducing the maize grain yield.

Thus, this study was based on the hypothesis that spraying the herbicides bentazon and nicosulfuron at adequate doses in maize intercropped with $C$. spectabilis, prevents the competition from the latter, while allowing its recovery, and controls weeds without negatively affecting the maize yield. The objective was, therefore, to study the selectivity of the herbicides bentazon and nicosulfuron in Crotalaria, as well as the weed control and maize development in this intercropping system.

\section{MATERIAL AND METHODS}

Two field experiments were conducted, one in the period between 02/18/2014 and 07/15/2014, under second-crop ("safrinha") conditions $\left(21^{\circ} 14^{\prime}\right.$ $36^{\prime \prime} \mathrm{S}$ and $48^{\circ} 17^{\prime} 20^{\prime \prime} \mathrm{O}$, at $553 \mathrm{~m}$ altitude), and the other in the period between $11 / 21 / 2014$ and $04 / 28 / 2015$, under first-crop ("safra") conditions $\left(21^{\circ} 14^{\prime} 95^{\prime \prime} \mathrm{S}\right.$ and $48^{\circ} 17^{\prime} 08^{\prime \prime} \mathrm{O}$, at $574 \mathrm{~m}$ altitude). The herbicides and doses used in the study were selected based on exploratory experiments performed previously in plots at the same institution.

The soil in the experimental areas was classified as very clayey and clayey, with organic matter values of $20 \mathrm{~g} \mathrm{dm}^{-3}$ and $21 \mathrm{~g} \mathrm{dm}^{-3}$ in the second- and first-crop experiments, respectively. The total monthly rainfall and mean monthly temperature during the experimental periods are shown in Figure 1.

The experiments had a randomized complete block design, with 14 treatments and four replications. Eight different herbicide treatments were tested: bentazon ( 720 and $960 \mathrm{~g}$ a.i. ha ${ }^{-1}$ ), nicosulfuron (16 and $48 \mathrm{~g}$ a.i. $\left.\mathrm{ha}^{-1}\right)$, and bentazon + nicosulfuron $(720+16 ; 720+48 ; 960+16 ;$ and $960+48 \mathrm{~g}$ a.i. $\mathrm{ha}^{-1}$ ). In addition, six controls were set up: maize alone (with and without weeds), showy crotalaria alone (with and without weeds), and maize intercropped with showy crotalaria (with and without weeds).

Tillage of the controls without weeds (hoed controls) was performed by hoeing when the reemergence of plants was observed in the plots.

In the second-crop experiment, the plots were $14 \mathrm{~m}$ long and $2.28 \mathrm{~m}$ wide, including three rows of maize and six rows of showy crotalaria. The floor area consisted of the inner row of maize and four rows of showy crotalaria, $12 \mathrm{~m}$ in length, making up a total of $18.24 \mathrm{~m}^{2}$. In the first-crop experiment, the plots were $12 \mathrm{~m}$ long and $2.28 \mathrm{~m}$ wide, including three rows of maize and six rows of showy crotalaria. The floor area consisted of the inner row of maize and four rows of showy crotalaria, $10 \mathrm{~m}$ in length, making up a total of $15.2 \mathrm{~m}^{2}$. 


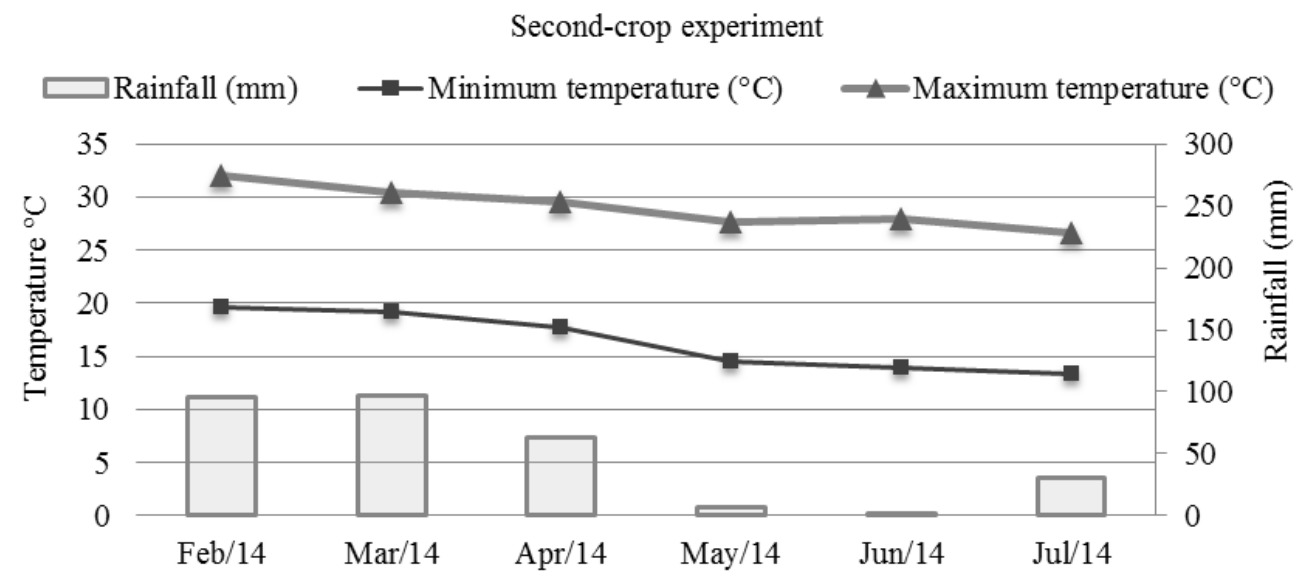

First-crop experiment

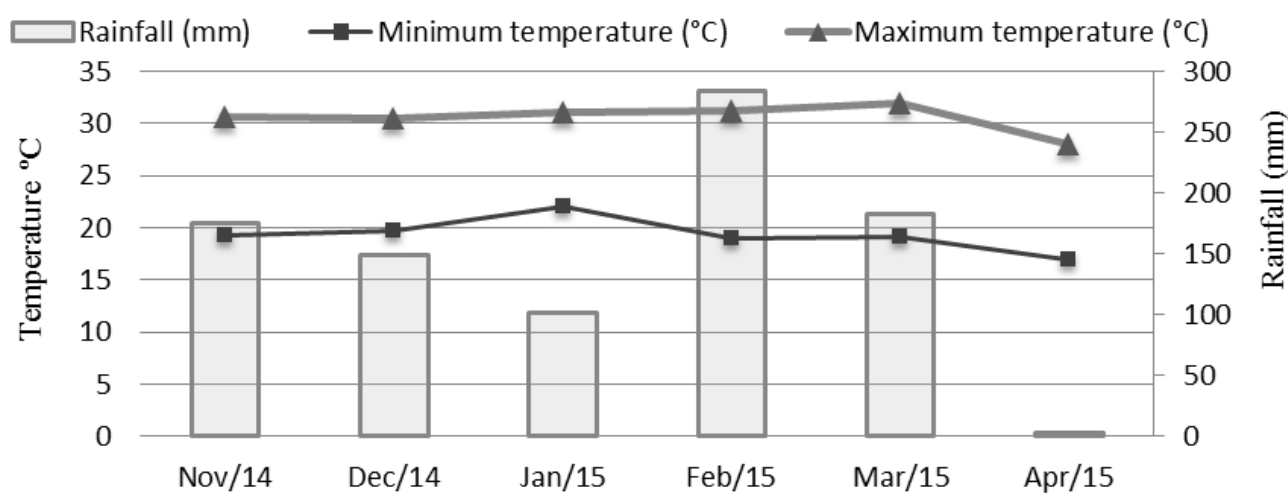

Figure 1. Total monthly rainfall and mean monthly minimum and maximum air temperatures. Recorded in the second-crop experiment, in the period between February and July 2014, and in the first-crop experiment, in the period between November 2014 and April 2015.

The soil was prepared using conventional methods, i.e., through plowing and harrowing. In the second-crop experiment, on $02 / 18 / 2014$, and in the first-crop experiment, on 11/21/2014, maize (DKB 390 PRO2) was planted at the same time as the showy crotalaria, with a spacing of $0.76 \mathrm{~m}$ between rows and seeding rate of 5 to 6 seeds per meter, at a 5 $\mathrm{cm}$ depth. The seeding rate of the showy crotalaria was 63 seeds per meter, sown in paired rows, with a spacing of $0.18 \mathrm{~m}$ between the rows of showy crotalaria and $0.29 \mathrm{~m}$ between the rows of showy crotalaria and maize. A SEMEATO SHM 11/13 notill seed drill planter was used.

A total of $300 \mathrm{~kg} \mathrm{ha}^{-1}$ of fertilizer (formula 08$28-16+0.3 \%$ of $\mathrm{Zn}$ ) was applied in-furrow. Topdressing nitrogen fertilization was performed at 17 days after sowing (DAS) (maize growth stage V4$\mathrm{V} 5$ ) in the second-crop and at 25 DAS (maize growth stage V5) in the first-crop, using $75 \mathrm{~kg} \mathrm{ha}^{-1}$ of nitrogen in the form of urea.

The herbicide treatments were applied at a 0.5 $\mathrm{m}$ spacing with a knapsack sprayer, equipped with a sprayer boom with four flat-fan spray nozzles (XR 11002 and DG 11002), at a constant pressure maintained by compressed $\mathrm{CO}_{2}\left(2.8 \mathrm{kgf} \mathrm{\textrm {cm } ^ { - 2 }}\right)$. The delivered solution was $150 \mathrm{~L} \mathrm{ha}^{-1}$ and $200 \mathrm{~L} \mathrm{ha}^{-1}$ in the second- and first-crop experiments, respectively. Mineral oil $(0.5 \% \mathrm{v} / \mathrm{v})$ was added to the solution in all treatments in which bentazon was applied.

At the time of the herbicide application, the C. spectabilis plants had a mean of 4.9 and 5 fully expanded leaves and were $2.9 \mathrm{~cm}$ and $4 \mathrm{~cm}$ in height in the second- and first-crop experiments, respectively, and the maize was at the growth stage V4-V5 in both experiments. The eudicot weeds had between two and four and between four and six true leaves in the second- and first-crop experiments, respectively, and the monocot weeds had up to one tiller in both experiments.

The weed community in the second-crop experiment was composed of six eudicot species and three monocot species (Alternanthera tenella, Cenchrus echinatus, Commelina benghalensis, Cyperus rotundus, Indigofera hirsuta, Ipomoea grandifolia, Leonotis nepetaefolia, Merremia aegyptia, and Raphanus raphanistrum). The main species were $C$. benghalensis, $C$. echinatus, and $R$. raphanistrum. In the first-crop experiment, 14 eudicot species and three monocot species were identified (Acanthospermum hispidum, A. tenella, Amaranthus retroflexus, Amaranthus viridis, $C$. benghalensis, Eleusine indica, Ipomoea hirsuta, 
Ipomoea quamoclit, I. grandifolia, Parthenium hysterophorus, Phyllanthus tenellus, Portulaca oleracea, $R$. raphanistrum, Richardia brasiliensis, Senna obtusifolia, and Xanthium strumarium), with A. tenella, E. indica, and I. hirsuta being the main species.

Visual assessments for the control of the weed community were performed on a weekly basis. However, only the data collected at 14 and 42 days after application (DAA) of the herbicides, which corresponded to the second and last assessments, are presented. This evaluation was performed using a scale of scores from $0 \%$ to $100 \%$, where $0 \%$ means absence of visual damage and $100 \%$ means plant death (SBCPD, 1995). At 48 DAA, the aerial parts of the weeds were collected in two areas of $0.45 \mathrm{~m}^{2}$ each, randomly selected within the floor area of the plots, and the material was dried in a forced-air oven until a constant weight was reached. The dry matter was subsequently quantified.

Damage to the $C$. spectabilis plants was visually assessed at 7, 14, and 42 DAA of the herbicides and a score between 0 and 100 was assigned (SBCPD, 1995).

The stand (in two center rows in a $2 \mathrm{~m}$ length), height of 10 plants (sequentially in the row), and Crotalaria dry matter were quantified at 90 DAA of the herbicides. To quantify the dry matter, the aerial parts of the showy crotalaria plants were collected in four areas of $0.19 \mathrm{~m}^{2}$ each, selected within the floor area of the plot, and the material was dried in a forced-air oven until a constant weight was reached. The results were estimated in $\mathrm{kg} \mathrm{ha}^{-1}$.

Plant population was assessed at 112 DAA of the herbicides in the second-crop experiment and at 132 DAA in the first-crop experiment, by counting the number of plants in a $2 \mathrm{~m}$ length of the center row. Maize grains were collected at 147 and 158
DAS in the second- and first-crop experiments, respectively. For this purpose, maize cobs were manually collected from a $12 \mathrm{~m}$ length of the center row in the second-crop experiment and from a $10 \mathrm{~m}$ length in the first-crop experiment. Subsequently, the maize cobs were mechanically threshed, after which the grain moisture was adjusted to $13 \%$. Production per plot was estimated in $\mathrm{kg} \mathrm{ha}^{-1}$, to obtain the grain yield. In addition, the mass of 400 grains was calculated.

The data obtained underwent the F-test of the analysis of variance method. The effects of the treatments with herbicides/controls, when significant, were compared using the Scott-Knott test $(\mathrm{p}<0.05)$. The weed dry matter data were logtransformed $(\log (x+1))$.

\section{RESULTS AND DISCUSSION}

A significant effect of the treatments was observed in terms of the weed control and dry matter of the aerial part of the weeds in both the secondand first-crop experiments (Tables 1 and 2).

In both experiments, nicosulfuron, at the highest dose and combined with bentazon, provided the highest weed control scores. Whereas, the use of bentazon alone resulted in the lowest mean scores. It has been shown that this herbicide is not effective in the control of the species $A$. tenella, I. hirsuta, and $C$. benghalensis at a dose of $720 \mathrm{~g}$ a.i. ha ${ }^{-1}$ (FERREIRA; MACHADO NETO; MATUO, 1998). However, there are reports of an effective control of the species $C$. difformis at the doses of 600 and $900 \mathrm{~g}$ a.i. ha $^{-1}$ (GALON et al., 2008; AGOSTINETTO et al., 2011) and of the species A. hispidum, Bidens pilosa, and Galinsoga parviflora at the dose of $840 \mathrm{~g}$ a.i. $\mathrm{ha}^{-1}$ (FONTES et al., 2001).

Table 1. Weed control scores at 14 and 42 days after application (DAA) of the herbicides and the dry matter of the aerial part of the weeds at $48 \mathrm{DAA}$, in plots with maize intercropped with Crotalaria spectabilis, and in the controls without herbicide application - second-crop experiment.

\begin{tabular}{|c|c|c|c|c|}
\hline \multirow{2}{*}{ Herbicides/Controls ${ }^{(1)}$} & \multirow{2}{*}{$\begin{array}{l}\text { Dose } \\
\qquad\left(\mathrm{g} \mathrm{ha}^{-1}\right)\end{array}$} & \multicolumn{2}{|c|}{ Control (\%) - DAA } & \multirow{2}{*}{$\begin{array}{l}\text { Dry matter } \\
\qquad\left(\mathrm{g} \mathrm{m}^{-1}\right)\end{array}$} \\
\hline & & 14 & 42 & \\
\hline 1. Bentazon & 720 & $33.8 \mathrm{c}^{(2)}$ & $22.5 \mathrm{c}$ & $0.7 \mathrm{e}$ \\
\hline 2. Bentazon & 960 & $20.0 \mathrm{c}$ & $15.0 \mathrm{c}$ & $0.5 \mathrm{e}$ \\
\hline 3. Nicosulfuron & 16 & $38.8 \mathrm{~b}$ & $51.3 \mathrm{~b}$ & $0.7 \mathrm{e}$ \\
\hline 4. Nicosulfuron & 48 & $43.8 \mathrm{~b}$ & $56.3 \mathrm{~b}$ & $0.2 \mathrm{~d}$ \\
\hline 5. Bentazon + nicosulfuron & $720+16$ & $36.3 \mathrm{~b}$ & $45.0 \mathrm{~b}$ & $0.1 \mathrm{~d}$ \\
\hline 6. Bentazon + nicosulfuron & $720+48$ & $60.0 \mathrm{a}$ & $75.0 \mathrm{a}$ & $0.2 \mathrm{~d}$ \\
\hline 7. Bentazon + nicosulfuron & $960+16$ & $38.8 \mathrm{~b}$ & $51.3 \mathrm{~b}$ & $0.1 \mathrm{~d}$ \\
\hline 8. Bentazon + nicosulfuron & $960+48$ & $65.0 \mathrm{a}$ & $80.0 \mathrm{a}$ & $0.3 \mathrm{~d}$ \\
\hline 9. Intercropping with weeds & & 0.0 & 0.0 & $1.0 \mathrm{c}$ \\
\hline 10. Maize with weeds & & 0.0 & 0.0 & $1.3 \mathrm{~b}$ \\
\hline 11. Showy crotalaria with weeds & & 0.0 & 0.0 & $2.1 \mathrm{a}$ \\
\hline $\mathrm{F}$ & & $9.3 * *$ & $13.9^{* *}$ & $17.3^{* *}$ \\
\hline CV (\%) & & 22.6 & 24.5 & 448 \\
\hline
\end{tabular}

${ }^{(1)}$ The weed control scores of the controls without herbicide application were not included in the statistical analyses; ${ }^{(2)}$ Means followed by the same letter did not differ statistically, according to the Scott-Knott test ( $\mathrm{p}<0.05)$; **Significant $(\mathrm{p}<0.01)$, according to the F-test of the analysis of variance. 
Table 2. Weed control scores at 14 and 42 days after application (DAA) of the herbicides and the dry matter of the aerial part of the weeds at 48 DAA, in plots with maize intercropped with Crotalaria spectabilis, and in the controls without herbicide application - first-crop experiment.

\begin{tabular}{lcccc}
\hline \multirow{2}{*}{ Herbicides/Controls $^{(1)}$} & Dose & \multicolumn{2}{c}{ Control (\%) - DAA } & Dry matter \\
& $\left(\mathrm{g} \mathrm{ha}^{-1}\right)$ & 14 & 42 & $\left(\mathrm{~g} \mathrm{~m}^{-1}\right)$ \\
\hline 1. Bentazon & 720 & $0.0 \mathrm{c}^{(2)}$ & $3.1 \mathrm{c}$ & $2.3 \mathrm{a}$ \\
2. Bentazon & 960 & $8.1 \mathrm{c}$ & $8.1 \mathrm{c}$ & $1.9 \mathrm{~b}$ \\
3. Nicosulfuron & 16 & $28.8 \mathrm{~b}$ & $25.6 \mathrm{~b}$ & $1.6 \mathrm{c}$ \\
4. Nicosulfuron & 48 & $81.9 \mathrm{a}$ & $80.6 \mathrm{a}$ & $1.0 \mathrm{~d}$ \\
5. Bentazon + nicosulfuron & $720+16$ & $27.5 \mathrm{~b}$ & $26.3 \mathrm{~b}$ & $1.4 \mathrm{c}$ \\
6. Bentazon + nicosulfuron & $720+48$ & $85.6 \mathrm{a}$ & $78.1 \mathrm{a}$ & $0.8 \mathrm{~d}$ \\
7. Bentazon + nicosulfuron & $960+16$ & $35.0 \mathrm{~b}$ & $40.0 \mathrm{~b}$ & $1.4 \mathrm{c}$ \\
8. Bentazon + nicosulfuron & $960+48$ & $77.5 \mathrm{a}$ & $73.8 \mathrm{a}$ & $0.8 \mathrm{~d}$ \\
9. Intercropping with weeds & & 0.0 & 0.0 & $2.1 \mathrm{~b}$ \\
10. Maize with weeds & & 0.0 & 0.0 & $2.2 \mathrm{~b}$ \\
11. Showy crotalaria with weeds & & 0.0 & 0.0 & $2.6 \mathrm{a}$ \\
\hline F & & $98.7^{* *}$ & $81.7^{* *}$ & $20.9^{* *}$ \\
CV (\%) & 15.9 & 16.7 & 16.3 \\
\hline
\end{tabular}

${ }^{(1)}$ The weed control scores of the controls without herbicide application were not included in the statistical analyses;

${ }^{(2)}$ Means followed by the same letter did not differ statistically, according to the Scott-Knott test $(\mathrm{p}<0.05)$; **Significant $(\mathrm{p}<0.01)$, according to the F-test of analysis of variance.

In the second-crop experiment, the lowest accumulation of weed dry mass was obtained with the mixture of bentazon and nicosulfuron at the doses of $720+16,720+48$, and $960+16$ g a.i. ha ${ }^{-1}$ and with nicosulfuron alone at $48 \mathrm{~g}$ a.i. ha ${ }^{-1}$. In the first-crop experiment, the association of bentazon with nicosulfuron, at the doses of $960+48$ and $720+$ $48 \mathrm{~g}$ a.i. $\mathrm{ha}^{-1}$, and nicosulfuron alone (48 $\mathrm{g}$ a.i. $\left.\mathrm{ha}^{-1}\right)$ provided the lowest mean values. In both experiments, the highest accumulation of weed dry mass occurred in the treatment with showy crotalaria alone + weeds, a result that differed from those for the remaining treatments, except bentazon used alone $\left(720 \mathrm{~g}\right.$ a.i. $\left.\mathrm{ha}^{-1}\right)$ in the first-crop experiment.

This result demonstrated that there was little competition between the legume species and weeds, as the former did not interfere with the development of the latter. Similarly, Correia, Fuzita and Daniel (2012) reported that the legumes Arachis pintoi and Calopogonium mucunoides did not affect the weeds when intercropped with maize. Additionally, Heinrichs et al. (2005) also did not observe a suppressing effect of Mucuna deeringiana, Cajanus cajan, and C. spectabilis when intercropped with maize. However, after the cultivation of $C$. spectabilis, Erasmo et al. (2004) obtained a reduction in the number of plants and weed dry mass, which they attribute to a possible allelopathic effect of this species.

There was a significant effect of the treatments on the assessed characteristics of showy crotalaria, in both experiments (Tables 3 and 4).

In the second-crop experiment, the use of bentazon alone (at the dose of $720 \mathrm{~g}$ a.i. $\mathrm{ha}^{-1}$ in all assessment periods and $960 \mathrm{~g}$ a.i. $\mathrm{ha}^{-1}$ from 14 DAA onward) resulted in the lowest phytotoxicity in $C$. spectabilis. In contrast, the mixture of bentazon and nicosulfuron at $960+48 \mathrm{~g}$ a.i. $\mathrm{ha}^{-1}$ resulted in the greatest visual damage in all assessment periods, and its effects did not differ from those of nicosulfuron alone $\left(16 \mathrm{~g}\right.$ a.i. ha $\left.{ }^{-1}\right)$, the mixture of bentazon + nicosulfuron at the doses of $720+16$ and $720+48 \mathrm{~g}$ a.i. ha ${ }^{-1}$ at 7 DAA, nicosulfuron alone $\left(48 \mathrm{~g}\right.$ a.i. $\left.\mathrm{ha}^{-1}\right)$ at $14 \mathrm{DAA}$, or nicosulfuron at the highest dose (48 $\mathrm{g}$ a.i. $\mathrm{ha}^{-1}$ ), alone or mixed with bentazon, at 42 DAA.

In the first-crop experiment, the use of bentazon alone, regardless of dose, provided the lowest phytotoxicity scores. Whereas, nicosulfuron alone (48 g a.i. ha $\left.{ }^{-1}\right)$, its combination with bentazon $\left(960+48 \mathrm{~g}\right.$ a.i. $\left.\mathrm{ha}^{-1}\right)$ in all assessment periods, and the same combination at $720+48 \mathrm{~g}$ a.i. $\mathrm{ha}^{-1}$ from 14 DAA onward, caused the greatest visual damage in showy crotalaria.

With regards to the dry matter, the greatest accumulation of mass occurred in the hoed control. In the second-crop experiment, the comparison of the two showy crotalaria controls (with and without weeds) showed a reduction of over $50 \%$ in the infested control, and the comparison between these two controls and intercropped maize showed a reduction of over $94 \%$. 
Table 3. Phytotoxicity scores obtained at 7, 14, and 42 days after application (DAA) of the herbicides, as well as the plant population, plant height, and dry matter of the aerial part of Crotalaria spectabilis intercropped with maize and of the controls, without herbicide application, at 90 DAA - second-crop experiment.

\begin{tabular}{|c|c|c|c|c|c|c|c|}
\hline \multirow{2}{*}{ Herbicides/Controls ${ }^{(1)}$} & \multirow{2}{*}{$\begin{array}{l}\text { Dose } \\
\left(\mathrm{g} \mathrm{ha}^{-1}\right)\end{array}$} & \multicolumn{3}{|c|}{ Phytotoxicity (\%) DAA } & \multirow{2}{*}{$\begin{array}{l}\text { Population } \\
\left(1000 \mathrm{pl} \cdot \mathrm{ha}^{-1}\right)\end{array}$} & \multirow{2}{*}{$\begin{array}{l}\text { Height } \\
\text { (m) }\end{array}$} & \multirow{2}{*}{$\begin{array}{l}\text { Dry matter } \\
\left(\mathrm{kg} \mathrm{ha}^{-1}\right)\end{array}$} \\
\hline & & 7 & 14 & 42 & & & \\
\hline 1. Bentazon & 720 & $5.3 \mathrm{c}^{(2)}$ & $5.2 \mathrm{c}$ & $27.8 \mathrm{~d}$ & $55.9 \mathrm{c}$ & $0.3 \mathrm{~d}$ & $159.8 \mathrm{c}$ \\
\hline 2. Bentazon & 960 & $22.8 \mathrm{~b}$ & $11.3 \mathrm{c}$ & $32.5 \mathrm{~d}$ & $36.2 \mathrm{c}$ & $0.3 \mathrm{~d}$ & $109.2 \mathrm{c}$ \\
\hline 3. Nicosulfuron & 16 & $27.5 \mathrm{a}$ & $32.5 \mathrm{~b}$ & $54.5 \mathrm{c}$ & $19.7 \mathrm{c}$ & $0.1 \mathrm{f}$ & $68.7 \mathrm{c}$ \\
\hline 4. Nicosulfuron & 48 & $21.3 \mathrm{~b}$ & $55.0 \mathrm{a}$ & $81.3 \mathrm{a}$ & $0.0 \mathrm{c}$ & $0.0 \mathrm{f}$ & $0.0 \mathrm{c}$ \\
\hline 5. Bentazon + nicosulfuron & $720+16$ & $30.0 \mathrm{a}$ & $36.3 \mathrm{~b}$ & $67.8 \mathrm{~b}$ & $32.9 \mathrm{c}$ & $0.2 \mathrm{e}$ & $54.7 \mathrm{c}$ \\
\hline 6. Bentazon + nicosulfuron & $720+48$ & $30.0 \mathrm{a}$ & $36.3 \mathrm{~b}$ & $84.5 \mathrm{a}$ & $9.9 \mathrm{c}$ & $0.1 \mathrm{f}$ & $29.8 \mathrm{c}$ \\
\hline 7. Bentazon + nicosulfuron & $960+16$ & $22.5 \mathrm{~b}$ & $38.3 \mathrm{~b}$ & $50.8 \mathrm{c}$ & $49.3 \mathrm{c}$ & $0.2 \mathrm{e}$ & $72.3 \mathrm{c}$ \\
\hline 8. Bentazon + nicosulfuron & $960+48$ & $37.5 \mathrm{a}$ & $61.3 \mathrm{a}$ & $89.0 \mathrm{a}$ & $9.9 \mathrm{c}$ & $0.1 \mathrm{f}$ & $24.5 \mathrm{c}$ \\
\hline 9. Intercropping with weeds & & 0.0 & 0.0 & 0.0 & $177.6 \mathrm{~b}$ & $0.6 \mathrm{c}$ & $416.4 \mathrm{c}$ \\
\hline 10. Intercropping without weeds & & 0.0 & 0.0 & 0.0 & $138.2 \mathrm{~b}$ & $0.6 \mathrm{c}$ & $459.4 \mathrm{c}$ \\
\hline 11. Showy crotalaria with weeds & & 0.0 & 0.0 & 0.0 & $154.6 \mathrm{~b}$ & $1.0 \mathrm{~b}$ & $3467.5 \mathrm{~b}$ \\
\hline 12. Showy crotalaria without weeds & & 0.0 & 0.0 & 0.0 & $230.3 \mathrm{a}$ & $1.1 \mathrm{a}$ & $7546.3 \mathrm{a}$ \\
\hline $\mathrm{F}$ & & $8.4 * *$ & $10.9^{* *}$ & $26.1 * *$ & $12.5 * *$ & $99.6 * *$ & $46.7^{* *}$ \\
\hline $\mathrm{CV}(\%)$ & & 26.5 & 33.5 & 15.1 & 57.7 & 20.8 & 64.2 \\
\hline
\end{tabular}

${ }^{(1)}$ The phytotoxicity scores of the controls without herbicide application were not included in the statistical analyses; ${ }^{(2)}$ Means followed by the same letter did not differ statistically, according to the Scott-Knott test $(\mathrm{p}<0.05)$; * Significant ( $p<0.01)$, according to the F-test of analysis of variance.

Table 4. Phytotoxicity scores obtained at 7, 14, and 42 days after application (DAA) of the herbicides, as well as the plant population, plant height, and dry mass of the aerial part of Crotalaria spectabilis intercropped with maize and of the controls, without herbicide application, at $90 \mathrm{DAA}$ - first-crop experiment.

\begin{tabular}{lccccccc}
\hline Herbicides/Controls ${ }^{(1)}$ & $\begin{array}{c}\text { Dose } \\
\left(\mathrm{g} \mathrm{ha}^{-1}\right)\end{array}$ & \multicolumn{2}{c}{ Phytotoxicity (\%) DAA } & $\begin{array}{c}\text { Population } \\
\left(1000 \mathrm{pl}^{-1}\right)\end{array}$ & $\begin{array}{c}\text { Height } \\
(\mathrm{m})\end{array}$ & $\begin{array}{c}\text { Dry matter } \\
\left(\mathrm{kg} \mathrm{ha}^{-1}\right)\end{array}$ \\
\hline 1. Bentazon & 720 & $0.6 \mathrm{e}^{(2)}$ & $0.0 \mathrm{~d}$ & $8.8 \mathrm{c}$ & $79.0 \mathrm{~b}$ & $1.1 \mathrm{c}$ & $396.2 \mathrm{e}$ \\
2. Bentazon & 960 & $5.0 \mathrm{e}$ & $4.6 \mathrm{~d}$ & $9.1 \mathrm{c}$ & $100.9 \mathrm{~b}$ & $1.0 \mathrm{~d}$ & $276.4 \mathrm{e}$ \\
3. Nicosulfuron & 16 & $25.6 \mathrm{~d}$ & $28.1 \mathrm{c}$ & $35.9 \mathrm{~b}$ & $223.7 \mathrm{~b}$ & $0.8 \mathrm{e}$ & $430.5 \mathrm{e}$ \\
4. Nicosulfuron & 48 & $64.4 \mathrm{a}$ & $73.1 \mathrm{a}$ & $79.7 \mathrm{a}$ & $125.0 \mathrm{~b}$ & $0.5 \mathrm{~g}$ & $228.8 \mathrm{e}$ \\
5. Bentazon + nicosulfuron & $720+16$ & $35.0 \mathrm{c}$ & $29.1 \mathrm{c}$ & $35.6 \mathrm{~b}$ & $166.7 \mathrm{~b}$ & $0.8 \mathrm{e}$ & $374.3 \mathrm{e}$ \\
6. Bentazon + nicosulfuron & $720+48$ & $52.5 \mathrm{~b}$ & $61.3 \mathrm{a}$ & $69.8 \mathrm{a}$ & $116.2 \mathrm{~b}$ & $0.4 \mathrm{~g}$ & $188.6 \mathrm{e}$ \\
7. Bentazon + nicosulfuron & $960+16$ & $48.8 \mathrm{~b}$ & $50.0 \mathrm{~b}$ & $41.3 \mathrm{~b}$ & $182.0 \mathrm{~b}$ & $0.8 \mathrm{e}$ & $483.6 \mathrm{e}$ \\
8. Bentazon + nicosulfuron & $960+48$ & $65.6 \mathrm{a}$ & $68.5 \mathrm{a}$ & $70.6 \mathrm{a}$ & $190.8 \mathrm{~b}$ & $0.6 \mathrm{f}$ & $401.8 \mathrm{e}$ \\
9. Intercropping with weeds & & 0.0 & 0.0 & 0.0 & $109.7 \mathrm{~b}$ & $1.2 \mathrm{~b}$ & $1121.2 \mathrm{~d}$ \\
10. Intercropping without weeds & & 0.0 & 0.0 & 0.0 & $230.3 \mathrm{~b}$ & $1.3 \mathrm{~b}$ & $1742.3 \mathrm{c}$ \\
1. Showy crotalaria with weeds & & 0.0 & 0.0 & 0.0 & $122.8 \mathrm{~b}$ & $1.5 \mathrm{a}$ & $5100.5 \mathrm{~b}$ \\
12. Showy crotalaria without weeds & & 0.0 & 0.0 & 0.0 & $396.9 \mathrm{a}$ & $1.6 \mathrm{a}$ & $9957.9 \mathrm{a}$ \\
\hline F & $54.0^{* *}$ & $35.0^{* *}$ & $37.7^{* *}$ & $3.8^{* *}$ & $41.6^{* *}$ & $216.3^{* *}$ \\
\hline CV (\%) & 18.4 & 24.3 & 20.4 & 57.1 & 12.6 & 23.1 \\
\hline
\end{tabular}

${ }^{(1)}$ The phytotoxicity scores of the controls without herbicide application were not included in the statistical analyses; ${ }^{(2)}$ Means followed by the same letter did not differ statistically, according to the Scott-Knott test $(\mathrm{p}<0.05)$; **Significant ( $p<0.01$ ), according to the F-test of analysis of variance.

In the first-crop experiment, the occurrence of weeds in the showy crotalaria control promoted a reduction of almost $5 \mathrm{t} \mathrm{ha}^{-1}$ in dry mass production. Comparison between the controls without weeds (sole and intercropped) revealed a decrease of $82.5 \%$ in the production of mass by the showy crotalaria plants in the intercropped system relative to the sole crop. These results demonstrated that maize and weeds interfered significantly with the development of Crotalaria. The herbicides drastically affected the development of the showy crotalaria plants with regard to stand, height, and dry mass, especially during the second-crop experiment.

In a study conducted by Gitti et al. (2012), there was a reduction in the dry mass of more than 6 $\mathrm{t} \mathrm{ha}^{-1}$ in C. Spectabilis intercropped with maize, sown at the same time, relative to the sole legume crop. In another study, there was a lower accumulation of dry mass by intercropped $C$. spectabilis than by the species Cajanus cajan, Dolichos lablab, and Stizolobium aterrimum, sown simultaneously with maize and 21 days after the maize planting (MARTINS, 1994). In the present study, this effect was amplified by the use of herbicides, which also interfered with the development of Crotalaria and, as a result, with biomass accumulation by the plants.

These results may be explained by the slow initial growth and $\mathrm{C}_{3}$ photosynthetic metabolism of the $C$. Spectabilis plants, whose competition with maize reflected negatively on biomass accumulation. In a study by Braz et al. (2015), to test the selectivity of herbicides in C. spectabilis under greenhouse 
conditions, the sub-doses of bentazon resulted in low phytotoxicity, whereas nicosulfuron resulted in moderate visual damage. However, under field conditions, because of the interspecific competition for available resources, such as water, light, and nutrients, and the absence of control over water and climatic factors, the recovery of the showy crotalaria plants from the toxic effects of herbicides was compromised.

In general, the showy crotalaria plants in the first-crop experiment accumulated more mass than those grown during the second-crop experiment. This is explained by the greater availability of water and the response of this species to the photoperiod, which promotes greater vegetative growth during the spring -summer period. This effect was observed in the study conducted by Cesar et al. (2011), in which the production of dry matter by the $C$. spectabilis plants was $5.56 \mathrm{t} \mathrm{ha}^{-1}$ and $2.28 \mathrm{t} \mathrm{ha}^{-1}$ in the spring-summer and autumn-winter periods, respectively. Moreover, bentazon applied alone at 720 and $960 \mathrm{~g} \mathrm{ha}^{-1}$ was the most selective herbicide in the showy crotalaria plants, in both experiments. Nevertheless, its control of weeds was less effective than that of the other chemical treatments.

The assessment of maize showed that the herbicides applied alone or combined did not cause visual damage to the crop, in both experiments.

In the second-crop experiment, there was no significant difference between the tested treatments with regard to the plant population, mass of 400 grains, and maize grain yield (Table 5).
Under the first-crop conditions, the treatments had an effect on the plant population and grain yield (Table 6). Nicosulfuron (48 g a.i. ha ${ }^{-1}$ ) and the mixtures with bentazon $(720+16$ and $720+48 \mathrm{~g}$ a.i. $\mathrm{ha}^{-1}$ ) promoted the greatest plant populations. With regard to the grain yield, maize alone and intercropped with weeds, as well as bentazon alone at the lowest dose $\left(720 \mathrm{~g}\right.$ a.i. $\left.\mathrm{ha}^{-1}\right)$, resulted in the lowest mean values and differed from the remaining herbicide treatments.

Competition with weeds, with conditions being more favorable for weed development in the spring-summer period, combined with the ineffective control of the herbicide bentazon applied alone at the lowest dose, was probably the cause of the negative effect on maize grain yield, which led to a result similar to that obtained in the maize control with weeds.

The use of the herbicide nicosulfuron did not affect maize grain yield because it provided the best weed control, thereby avoiding the competition of the weeds with maize. In a study conducted by Moraes et al. (2013), the treatments with nicosulfuron resulted in increased grain yields, regardless of the cover crop and adopted control method (cutting or desiccation with herbicides) before maize planting. However, other factors should be considered in the present intercropping system, such as the development of the Crotalaria plants, which was severely affected by the use of nicosulfuron.

Table 5. Plant population, mass of 400 grains, and grain yield of maize intercropped with Crotalaria spectabilis and of the controls without herbicide application, at 112 days after application (DAA) of the herbicides - second-crop experiment.

\begin{tabular}{|c|c|c|c|c|}
\hline Herbicides/Controls & $\begin{array}{c}\text { Dose } \\
\left(\mathrm{g} \mathrm{ha}^{-1}\right)\end{array}$ & $\begin{array}{c}\text { Population } \\
\left.\left(1000 \text { plants }^{-1}\right)^{-1}\right)\end{array}$ & $\begin{array}{l}\text { Mass of } 400 \\
\text { grains }(\mathrm{g})\end{array}$ & $\begin{array}{l}\text { Grain yield } \\
\left(\mathrm{kg} \mathrm{ha}^{-1}\right)\end{array}$ \\
\hline 1. Bentazon & 720 & $62.8 \mathrm{a}^{(1)}$ & $116.2 \mathrm{a}$ & $6.076 \mathrm{a}$ \\
\hline 2. Bentazon & 960 & $63.1 \mathrm{a}$ & $114.0 \mathrm{a}$ & $5.706 \mathrm{a}$ \\
\hline 3. Nicosulfuron & 16 & $60.9 \mathrm{a}$ & $108.7 \mathrm{a}$ & $5.264 \mathrm{a}$ \\
\hline 4. Nicosulfuron & 48 & $62.8 \mathrm{a}$ & $117.5 \mathrm{a}$ & $5.995 \mathrm{a}$ \\
\hline 5. Bentazon + nicosulfuron & $720+16$ & $63.9 \mathrm{a}$ & $111.8 \mathrm{a}$ & $6.179 \mathrm{a}$ \\
\hline 6. Bentazon + nicosulfuron & $720+48$ & $64.7 \mathrm{a}$ & $116.6 \mathrm{a}$ & $5.690 \mathrm{a}$ \\
\hline 7. Bentazon + nicosulfuron & $960+16$ & $62.8 \mathrm{a}$ & $117.4 \mathrm{a}$ & $5.678 \mathrm{a}$ \\
\hline 8. Bentazon + nicosulfuron & $960+48$ & $66.6 \mathrm{a}$ & $118.3 \mathrm{a}$ & $5.260 \mathrm{a}$ \\
\hline 9. Maize with weeds & & $62.5 \mathrm{a}$ & $110.4 \mathrm{a}$ & $5.263 \mathrm{a}$ \\
\hline 10. Maize without weeds & & $62.2 \mathrm{a}$ & $111.8 \mathrm{a}$ & $5.670 \mathrm{a}$ \\
\hline 11. Intercropping with weeds & & $63.6 \mathrm{a}$ & $108.3 \mathrm{a}$ & $5.797 \mathrm{a}$ \\
\hline 12. Intercropping without weeds & & $61.7 \mathrm{a}$ & $118.0 \mathrm{a}$ & $5.476 \mathrm{a}$ \\
\hline $\mathrm{F}$ & & $0.44^{\mathrm{ns}}$ & $1.96^{\mathrm{ns}}$ & $0.85^{\mathrm{ns}}$ \\
\hline $\mathrm{CV}(\%)$ & & 7.1 & 4.7 & 10.4 \\
\hline
\end{tabular}

${ }^{(1)}$ Means followed by the same letter do not differ statistically, according to the Scott-Knott test $(\mathrm{p}<0.05)$; ns: not significant, according to the $\mathrm{F}$ test of the analysis of variance. 
Table 6. Plant population, mass of 400 grains, and grain yield of maize intercropped with Crotalaria spectabilis and of the controls without herbicide application, at 132 days after application (DAA) of the herbicides - first-crop experiment.

\begin{tabular}{lcccc}
\hline Herbicides/Controls & $\begin{array}{c}\text { Dose } \\
\left(\mathrm{g} \mathrm{ha}^{-1}\right)\end{array}$ & $\begin{array}{c}\text { Population } \\
\left(1000 \text { plants ha }^{-1}\right)\end{array}$ & $\begin{array}{c}\text { Mass of } 400 \\
\text { grains }(\mathrm{g})\end{array}$ & $\begin{array}{c}\text { Grain yield } \\
\left(\mathrm{kg} \mathrm{ha}^{-1}\right)\end{array}$ \\
\hline 1. Bentazon & 720 & $51.3 \mathrm{~b}^{(1)}$ & $158.5 \mathrm{a}$ & $7.791 \mathrm{~b}$ \\
2. Bentazon & 960 & $52.0 \mathrm{~b}$ & $162.5 \mathrm{a}$ & $9.642 \mathrm{a}$ \\
3. Nicosulfuron & 16 & $51.6 \mathrm{~b}$ & $163.5 \mathrm{a}$ & $9.847 \mathrm{a}$ \\
4. Nicosulfuron & 48 & $54.9 \mathrm{a}$ & $166.0 \mathrm{a}$ & $10.605 \mathrm{a}$ \\
5. Bentazon + nicosulfuron & $720+16$ & $55.9 \mathrm{a}$ & $162.5 \mathrm{a}$ & $10.100 \mathrm{a}$ \\
6. Bentazon + nicosulfuron & $720+48$ & $55.9 \mathrm{a}$ & $170.8 \mathrm{a}$ & $11.061 \mathrm{a}$ \\
7. Bentazon + nicosulfuron & $960+16$ & $49.0 \mathrm{~b}$ & $158.0 \mathrm{a}$ & $9.894 \mathrm{a}$ \\
8. Bentazon + nicosulfuron & $960+48$ & $49.3 \mathrm{~b}$ & $163.3 \mathrm{a}$ & $10.050 \mathrm{a}$ \\
9. Maize with weeds & & $49.0 \mathrm{~b}$ & $162.0 \mathrm{a}$ & $8.569 \mathrm{~b}$ \\
10. Maize without weeds & & $52.0 \mathrm{~b}$ & $165.5 \mathrm{a}$ & $10.470 \mathrm{a}$ \\
11. Intercropping with weeds & $52.3 \mathrm{~b}$ & $158.5 \mathrm{a}$ & $9.020 \mathrm{~b}$ \\
12. Intercropping without weeds & $49.7 \mathrm{~b}$ & $162.5 \mathrm{a}$ & $9.134 \mathrm{~b}$ \\
\hline F & & $2.1^{*}$ & $1.5^{\text {ns }}$ & $3.93^{* *}$ \\
CV (\%) & 6.7 & 3.7 & 9.6 \\
\hline
\end{tabular}

${ }^{(1)}$ Means followed by the same letter do not differ statistically, according to the Scott-Knott test $(\mathrm{p}<0.05)$; **, *Significant $(\mathrm{p}<0.01)$ and $(\mathrm{p}<0.05)$, according to the $\mathrm{F}$ test of the analysis of variance; ns: not significant according to the $F$ test of analysis of variance.

There was no difference in the grain yield between the intercropped controls without herbicide application and the sole maize crop without weeds. Similarly, Gitti et al. (2012) observed that when maize was sown at the same time as the legume, the maize grain yield was not affected. Kappes and Zancanaro (2015) studied species of Crotalaria and forage grasses and reported that intercropped $C$. Spectabilis planted in the maize sowing row caused a reduction in the grain yield by $4.6 \%$, being the less harmful system.

Because of the competitive characteristics of maize, such as the fast growth of plants and subsequent shading between rows, this crop is highly adaptable to intercropping systems, without suffering interference from the intercrop (DAN et al., 2012). Moreover, the C. Spectabilis species exhibits slow initial growth, smaller plants, and does not cause interspecific competition for the available resources that compromises the grain yield, independently of the water availability and photoperiod. These features are beneficial because they allow the mechanical harvesting of maize without indirect interference from the intercrop species. Moreover, intercropping promotes a higher degree of stover than does monocropping (GITTI et al., 2012; KAPPES; ZANCARANO, 2015) and the control of nematodes in the crop area (COSTA; PASQUALLI; PREVEDELLO, 2014).

Intercropping of maize and C. Spectabilis is, therefore, a favorable option for production systems. However, the success of this crop system depends upon the level of infestation and species of weeds present at the site, because this species has a low competitive ability and is sensitive to the herbicides registered for maize.

\section{CONCLUSION}

The herbicide bentazon used alone, at the two tested doses, was the most selective in C. spectabilis. Maize intercropped with $C$. spectabilis without herbicides, with or without weeds, provided the best results, when considering the maize yield, maize development, and production of dry matter of showy crotalaria.

\section{REFERENCES}

AGOSTINETTO, D. et al. Resistência de Cyperus difformis L. ao herbicida pyrazosulfuron-ethyl e alternativas de controle. Semina: Ciências agrárias, v. 32, n. 3, p. 839-848, 2011.

BRAZ, G. B. P. et al. Selection of herbicides targeting the use in crop systems cultivated with showy crotalaria. Planta Daninha, v. 33, n. 3, p. 521 $-534,2015$.

BRAZ, G. B. P. et al. Selectivity of herbicides applied in post-emergence of showy crotalaria. Revista Caatinga, v. 29, n. 4, p. 918-926, 2016.

CESAR, N. Z. et al. Performance de adubos verdes cultivados em duas épocas do ano no Cerrado do Mato Grosso do Sul. Revista Brasileira de Agroecologia, v. 6, n. 2, p. 159-169, 2011.

CORREIA, N. M.; DANIEL, B.; LEITE, M. B. Intercropping corn and kudzu in a rotation system with soybean. Acta Scientiarum, v. 34, n. 3, p. 309$315,2012$. 
CORREIA, N. M.; FUZITA, W. E.; DANIEL, B. Cultivo consorciado de milho com amendoim forrageiro e calopogônio e os efeitos na cultura da soja em rotação. Semina: Ciências Agrárias, v. 33, n. 2, p. 575-586, 2012.

COSTA, M. J. N.; PASQUALli, R. M.; PREVEDELLO, R. Efeito do teor de matéria orgânica do solo, cultura de cobertura e sistema de plantio no controle de Pratylenchus brachyurus em soja. Summa Phytopathologica, v. 40, n. 1, p. 6370, 2014.

DAN, H. G. et al. Controle de plantas daninhas em sistemas de cultivo consorciados. Revista Brasileira de Herbicidas, v. 11, n. 1, p. 108-118, 2012.

ERASMO, E. A. L. et al. Potencial de espécies utilizadas como adubo verde no manejo integrado de plantas daninhas. Planta Daninha, v. 22, n. 3, p. 337 $-342,2004$

FERREIRA, M. C.; MACHADO NETO, J. G.; MATUO, T. Redução da dose e do volume de calda nas aplicações noturnas de herbicidas em pósemergência na cultura da soja. Planta Daninha, v. 16, n. 1, p. $25-36,1998$.

FONTES, J. R. A. et al. Efeitos de herbicidas no controle de plantas daninhas na cultura do feijãomungo-verde (Vigna radiata L. Wilczek). Ciência e Agrotecnologia, v. 25, n. 5, p. 1087-1096, 2001.

GALVÃO, J. C. C. et al. Sete décadas de evolução do sistema produtivo da cultura do milho. Revista Ceres, v. 61, sup., p. 819-828, 2014.

GALON, L. et al. Resistência de Cyperus difformis a herbicidas inibidores da ALS em lavoura de arroz irrigado em Santa Catarina. Planta Daninha, v. 26, n. 2, p. 419-427, 2008.

GITTI, D. C. et al. Épocas de semeadura de crotalária em consórcio com milho. Revista Brasileira de Milho e Sorgo, v. 11, n. 2, p. 156-168, 2012.

HEINRICHS, R. et al. Soil chemical characteristics and green manure yield in a corn intercropped system. Revista Brasileira de Ciência do Solo, v. 29, n. 1, p. 71-79, 2005.

KAPPES, C.; ZANCANARO, L. Sistemas de consórcios de braquiária e de crotalárias com a cultura do milho. Revista Brasileira de Milho e Sorgo, v. 14, n. 2, p. 219-234, 2015.

MARTINS, D. Comunidade infestante no consórcio de milho com leguminosas. Planta Daninha, v. 12, n. 2, p. 100-105, 1994.
MATEUS, G. P.; WUTKE, E. B. Espécies de Leguminosas Utilizadas como Adubos Verdes. Pesquisa \& Tecnologia, v. 3, n. 1, p. 1-15, 2006.

MORAES, P. V. D. et al. Manejo de plantas de cobertura no controle de plantas daninhas e desempenho produtivo da cultura do milho. Semina: Ciências Agrárias, v. 34, n. 2, p. 497-508, 2013.

SANTOS, P. A. et al. Adubos verdes e adubação nitrogenada em cobertura no cultivo do milho. Revista Brasileira de Milho e Sorgo, v. 9, n. 2, p. 123-134, 2010.

SOCIEDADE BRASILEIRA DA CIÊNCIA DAS PLANTAS DANINHAS - SBCPD. Procedimentos para instalação, avaliação e análise de experimentos com herbicidas. Londrina - PR: SBCPD, 1995. $42 \mathrm{p}$. 